\title{
Om oor God te praat: 'n Kritiese oorsig van gesprekke onder Afrikaanssprekende Christene van die gereformeerde tradisie $(1998-2003)^{1}$
}

\author{
I J J Spangenberg \\ (Universiteit van Suid-Afrika)
}

\section{ABSTRACT}

Speaking about God: A critical review of debates amongst Afrikaansspeaking Christians of the reformed tradition (1998-2003)

The book Die vreemde God en sy mense (The enigmatic God and his people) - published in 1998 - marks the beginning of a new debate about God amongst Afrikaans-speaking people of the reformed tradition. The fall of the National Party government and the end of the Apartheid policy in 1994 forced theologians to reflect on the authority of the Bible; the issue of creation, the Big Bang and evolution; the relationship between Christianity and other religions; the historical Jesus research and the possibility of a new reformation. Afrikaans-speaking people suddenly became part of the global village and could not ignore these issues anymore. Four tendencies in the debates are identified: (1) clinging to the credos of the reformed tradition and adhering to the master narrative of Western Christianity; (2) looking at the credos as cultural and timeconditioned ones but trying to integrate the theories of the Big Bang and evolution with the master narrative of Christianity, (3) breaking away from the master narrative of Western Christianity and creating a new tradition; (4) abandoning the Christian tradition altogether and exploring another religious tradition, especially Buddhism.

\section{INLEIDING}

Alvorens 'n mens oor God kan praat, is dit noodsaaklik om uit te spel vanuit watter godsdienstradisie jy oor die "onderwerp" gaan praat. Doen jy dit nie, is die moontlikheid daar dat ander mense jou kan misverstaan, of dat hulle verwagtinge kan koester waaraan jy nie gaan voldoen nie. Wat hier volg is dus die perspektief van iemand wat in die Protestantse tradisie van die Christendom en meer spesifiek die gereformeerde tradisie groot geword het. In hierdie tradisie speel die Nederlandse Geloofsbelydenis, die

1 Die artikel is gebaseer op 'n lesing wat gelewer is op 14 Oktober 2003 tydens 'n geleentheid gereël deur die CB Powell Bybelsentrum aan Unisa. 
Heidelbergse Kategismus en die Dordtse Leerreëls 'n belangrike rol. Hierdie drie belydenisskrifte word dikwels voorgehou as onoortreflike vertolkings van die Bybel en as van die suiwerste beskrywings van die Christelike geloof.

Alhoewel ek as tiener aan die hand van hierdie belydenisdokumente gekatkiseer is en dit ook as teologiestudent moes bestudeer, het dit na jare se studie van die Bybel vir my duidelik geword dat hierdie dokumente nie voorgehou kan word as tydlose vertolkings van die Bybel nie. Hierdie dokumente weerspieël die interpretasies van teoloë wat in Europa van die sestiende en sewentiende eeu geleef het. Dit verraai dus hulle kennis- en leefwêreld ${ }^{2}$. Dit het ook mettertyd vir my duidelik geword dat die belydenisskrifte nie in die eerste plek op die Bybel gebaseer is nie, maar op ' $n$ verhaal wat nie in dáárdie vorm in die Bybel staan nie. Die opstellers van die belydenisdokumente het na regte die Bybel geïnterpreteer aan die hand van ' $n$ ander verhaal. Hierdie verhaal kan ons die meesterverhaal van die Westerse Christendom noem. Dit kan vandag nog in sy visuele vorm in die gebrandskilderde vensters van Europese katedrale en in die prentjiesboek Biblia Pauperum (vgl Henry 1987) gesien word. Ons kan daardie verhaal soos volg kortliks weergee:

Die ganse mensdom stam van een vader en moeder af, naamlik Adam en Eva. Hierdie eerste ouerpaar het egter ons almal se lot verseël toe hulle na die Satan geluister en God se gebod oortree het. Ons almal was bedoel om vir ewig te lewe, maar vanweë hulle ongehoorsaamheid in die tuin van Eden is ons almal bestem om te sterf.

Die hele Ou Testament vertel die verhaal van hoe God die weg voorberei het vir die koms van sy Seun wat bestem was om die mag van die Satan en die dood te verbreek. Jesus het op die bestemde tyd as die ewige Seun van God uit die hemel gekom en mens geword deur die maagd Maria. Hy het plaasvervangend onder God se oordeel aan die kruis vir die sondes van die ganse mensdom gesterf. Omdat Hy gehoorsaam was aan

2 Neem as voorbeeld artikel 36 van die Nederlandse Geloofsbelydenis. Daardie artikel staan die beginsel van cuius regio - eius religio voor, met ander woorde die beginsel van die eienaar van die gebied bepaal die godsdiens. Ons kan dit ook uitdruk as die regeerder bepaal die godsdiens. Hierdie beginsel is ook tydens die Nasionale Party regering (1948-1994) deurgevoer. Dit is die rede waarom gereformeerde predikante tydens staatsplegtighede opgetree het en die Christelike godsdiens voorrang geniet het. 
God se verlossingsplan en die kruisdood gewillig aanvaar het, het Hy die mag van die Satan en die dood verbreek. Die resultaat van hierdie soendood is dat ons almal nou weer vir ewig kan leef soos God dit van die begin van die skepping bedoel het.

Die bewys dat Jesus se sending geslaagd was, is bevestig deur sy hellevaart, sy opstanding, sy hemelvaart en die uitstorting van die Heilige Gees. Jesus sal aan die einde van die tyd weer kom om diegene wat in Hom geglo het - en dus sy soenoffer aanvaar het - met die ewige lewe te beloon, maar diegene wat Hom en sy soenoffer verwerp het, met die ewige dood in die hel te straf. Dáár heers die Satan en sy engele.

Alhoewel Protestantse Christene die Bybel as die basis van hulle geloof voorhou en meen dat die belydenisdokumente direk op die Bybel gebaseer is, is die meesterverhaal van die Christendom die eintlike basis van die geloof. Die Bybel is - en word steeds - aan die hand van die meesterverhaal gelees en uitgelê. David Ord en Robert Coote (1994:26) stel dit treffend wanneer hulle sê: "We read the Bible in the light of almost two thousand years of church tradition and theological reflection". Christene lees die Bybel nie onbevange en sonder voorveronderstellings nie. Die voorveronderstellings (of die "bril") aan die hand waarvan hulle die Bybel lees, is die meesterverhaal van die Christendom en dáárdie verhaal berus hoofsaaklik op die interpretasies van die Griekse en Latynse kerkvaders.

Wat ek dus hier aanbied, is my ervaring van hoe Afrikaanssprekende gereformeerde Christene oor die afgelope vyf jaar probleme met die meesterverhaal begin ervaar het. Die rede waarom sommige gelowiges ongemaklik raak met sekere dogmas en ander uiteindelik alle bande met die kerk breek, moet ons eerstens soek in die feit dat ons wêreldbeeld tans totaal anders lyk as die wêreldbeeld wat deur die meesterverhaal van die Christelike godsdiens veronderstel word. Günther Weber (1998:19) vat dit raak saam wanneer hy sê: "I now understand why the church is instinctively defensive about changes in world-views. Because the whole structure of its faith is grounded in the world-view of antiquity, any change in the world-view must shake the foundations of that structure".

Maar dis nie al rede nie. Die wetenskaplike studie van die Bybel die afgelope meer as drie eeue, het bo alle twyfel uitgewys dat die meesterverhaal die kreatiewe vertolking van teoloë uit die vierde en vyfde eeu is. Die 
meesterverhaal is nie maar net ' $\mathrm{n}$ bondige samevatting van dit wat die Bybel van Genesis tot Openbaring bied nie.

\section{DIE BEGIN VAN DIE GESPREK}

Vyf jaar gelede het die boek Die vreemde God en sy mense van Willem De Klerk (1998) 'n nuwe godsdiensdebat onder Afrikaanssprekendes ingelei. Hierdie debat het egter nie asof uit die niet verskyn nie. Reeds twee jaar tevore was die boek Die dag toe ons God gevang het: 'n Persoonlike soektog na sin van Annelie Ferreira (1996) op die rakke van die CNA en ander boekwinkels beskikbaar. In die boek het sy op 'n baie openhartige en eerlike manier vertel van haar soeke na sin en haar ervaring dat die tradisionele Christelike geloof op bepaalde punte eenvoudig nie meer sin maak en haar nie van 'n roetekaart voorsien vir haar lewensreis nie. Die prikkels vir haar nadenke is voorsien deur haar pa se dood tydens haar vroeë tienerjare, en haar ervaring van depressie na die geboorte van haar eerste kind.

Die uitgewery Queillerie wat haar boek gepubliseer het, het ' $n$ jaar daarna 'n man se soeke na sin gepubliseer. Tienie Swanepoel worstel in sy boek My hart wil Afrika (1997) met sy bestaan in Afrika. Die prikkels vir sy nadenke is voorsien deur die Christelik-Nasionale opvoeding wat hy op laer- en hoërskool ontvang het en sy ervaring van diensplig en die Grensoorlog. Alhoewel die boek nie primêr op die Christelike godsdiens fokus nie, is die Christelike godsdiens soos 'n gouedraad daarin verweef. Swanepoel het ook ervaar dat die tradisionele Christelike geloof in velerlei opsigte nie meer sin maak en nie antwoorde bied op die lewensvrae waarmee hy worstel nie. Sy kontak met die mense van Afrika en hulle kultuur $^{3}$ het 'n klomp Christelike leerstellings in die gedrang gebring en hy moes opnuut soek na oriëntasie en sin.

Willem de Klerk se boek het meer aandag getrek as Annelie Ferreira en Tienie Swanepoel se boeke. Miskien hang dit saam met die feit dat 'n gevestigde uitgewery soos Human en Rousseau dit uitgegee het. Miskien hang dit saam met die feit dat De Klerk 'n bekende in akademiese, kerklike en kulturele kringe is. Wat die rede(s) ookal mag wees, De Klerk se aanvoeling dat daar ' $n$ verskuiwing in Afrikaanssprekendes se

3 Tienie Swanepoel is 'n antropoloog en was tot onlangs toe direkteur van grondsake in KwaZulu/Natal. 
godsbesef en godsdiensbelewenis besig was om plaas te vind, is bevestig deur die boeke van Annelie Ferreira en Tienie Swanepoel.

\section{INTERMEZZO 1: DIE GROOT GEDAGTE}

In die jaar voorafgaande aan dié een waarin Willem de Klerk se boek uitgegee is, het Tafelberg 'n boek gepubliseer wat op 'n onbedoelde manier momentum aan die debat gegee het. Dit was Gideon Joubert se boek met die titel Die groot gedagte: Abstrakte weefsel van die kosmos (1997). Joubert het gewone lesers op 'n eenvoudige manier bekend gestel aan die astrofisika. Vir die eerste keer was daar in Afrikaans 'n boek beskikbaar wat begrippe soos "oerknal", "ruimtetyd", "kwasars", "swartkolke" en "uitdyende heelal" eenvoudig verduidelik het. Hierdie boek het bo verwagting goed verkoop en moes spoedig herdruk word. Wat nog verder verrassend was - en vir 'n groep Afrikaanssprekende kreasioniste ontstellend — is die feit dat dit in 1998 met die Andrew Murray-boekprys bekroon is.

Alhoewel die boek in die eerste plek 'n populêre wetenskaplike werk is, het Joubert tog 'n geloofsperspektief daarin verweef. Hierdie geloofsperspektief blyk die duidelikste in die volgende aanhaling (Joubert 1997:179): “Christus het die mens opdrag gegee om te soek. Die mens kán nie anders nie, want hy is so gemaak. [...] Vir die mens se soekende verstand openbaar God hom in die wetenskap; vir sy soekende gees in die Bybel"4. Hierdie stelling van Joubert kom grootliks ooreen met 'n stelling wat nog groot aanhang geniet in gereformeerde kringe. Bondig geformuleer staan dit bekend as "openbaring in die natuur en Skriftuur". God openbaar Hom volgens hierdie siening in sowel die natuur as in die Bybel

4 Joubert se godsdienstige stellings verraai dat hy nie vertroud is met die paradigmaverskuiwings op die terrein van die Bybelwetenskappe en die jongste gesprekke in die teologie nie. Hy werk nog grootliks met 'n tradisioneelgereformeerde Skrifbeskouing en neem die meesterverhaal van die Christendom as vertrekpunt vir sy geloofsperspektief (vgl Joubert 1997:290-300). Dis opvallend dat hy in hierdie aanhaling van Christus praat wat die mens die opdrag gegee het om te soek. Sodanige opdrag kom nêrens in die Nuwe Testament voor nie behalwe as hy aan Mat 7:7 gedink het. My vermoede is egter dat hierdie stelling op die opdrag in Gen 1:26-28 sinspeel. As dit die geval is, sou mens daarop kon wys dat Gen 1 alleen gewag maak dat God geskep het. Van Christus is hier nie sprake nie. Christene kan die idee van die Drie-eenheid nie eenvoudig in die $\mathrm{Ou}$ Testament inlees nie, want dan lees hulle anachronisties.

5 Vergelyk artikel 2 van die Nederlandse Geloofsbelydenis. 
en die twee openbarings is nooit weersprekend nie. Wanneer daar weersprekings voorkom, is dit óf die natuurwetenskaplikes, óf die teoloë wat die openbaring verkeerd vertolk (vgl Alberts 1996:23-29). Die botsing tussen die Katolieke Kerk en Galileo Galileï gedurende die sewentiende eeu word dikwels as 'n voorbeeld voorgehou van wanvertolkings van God se openbaring. Galileo Galileï het die openbaring in die natuur reg vertolk, maar die kerk het die openbaring in die Bybel verkeerd vertolk en daarom het daar 'n tragiese botsing voorgekom (vgl Kalsbeek 1968:24) ${ }^{6}$.

\section{NUWE RIGTING IN DIE GESPREK}

Gedurende 2000 het Ben du Toit met sy boek God? Geloof in ' $n$ postmoderne tyd (2000) heelwat oë laat rek met sy poging om die nuwere wetenskaplike feite (die oerknal en die evolusieleer) met die meesterverhaal van die Christelike godsdiens in verband te bring ${ }^{7}$. Vir die doel onderskei hy 'n premoderne, 'n moderne en 'n postmoderne tydvak in die geskiedenis van die mensdom. Hy gebruik Thomas Kuhn (1970) se idee van paradigmaveranderings om die verskille tussen die tydvakke te verduidelik en om te wys waarom Christene wat in die een-en-twintigste eeu leef, probleme ondervind met die Bybel en die sienings wat daarin voorkom. Alhoewel sy boek deur 'n aantal prominente Afrikaanssprekende teoloë hoog aangeslaan is ${ }^{8}$, het heelwat predikante en lidmate negatief daarop gereageer - veral nadat die boek met die Andrew Murray prys vir godsdienstige literatuur in 2001

$6 \quad$ Na my mening kan ons nie meer vandag met hierdie soort siening werk nie. Die Bybel is nie God se openbaring nie. Nog minder bevat dit God se openbaring. Indien ons nog met 'n begrip soos openbaring wil werk, kan ons hoogstens sê dat ons in die Bybel te doen kry met mense se getuienis oor die openbaring. In die woorde van John Barton (1988:56): "The Bible is people's reflection on their relationship with the known God: the knowledge, or revelation if you like, lies behind it rather than in it".

7 Ben du Toit gaan dus verder as Gideon Joubert en betrek ook die evolusieleer in die debat. Die opset van sy boek is egter anders as dié van Gideon Joubert. Hy verduidelik nie die tegniese aspekte van die oerknalteorie en die evolusieleer nie, maar aanvaar die feite soos populêre wetenskaplike publikasies dit aanbied. Sy oogmerk is om dit met die meesterverhaal van die Christelike godsdiens te integreer.

8 Die voorwoord is deur Wentzel van Huyssteen geskryf en op die agterblad van die boek verskyn 'n aanbeveling van Piet Naudé. 
bekroon is. Dit het dan ook vir heelwat polemiek in Die Kerkbode gesorg ${ }^{9}$. $\mathrm{Du}$ Toit het hom later aan die debat onttrek en te kenne gegee dat hy wel op versoek gemeentes sal besoek om sy standpunte te verduidelik.

In die eerste sestig bladsye van sy boek lê Du Toit die basis vir die res van sy argumente. Hierin skets hy kortliks hoe die kosmos deur 'n oerknal ontstaan en hoe lewe op aarde deur evolusie ontplooi het (Du Toit 2000:7-9, 13-43). Wanneer hy hierdie sienings met die Bybel en die meesterverhaal van die Christelike godsdiens in verband bring ( $\mathrm{Du}$ Toit 2000:63-184), duik daar inkonsekwenthede op.

Volgens hom kry 'n mens nooit met naakte feite te doen nie. Feite is altyd geïnterpreteerde data. "Hierdie feit", skryf hy, "is waar van alle literatuur, ook van die Bybelse geskrifte as literatuur" (Du Toit 2000:67). Hierdie uitspraak word later aan die hand van die drie tydperke soos volg uitgebrei: "Ons het in die Bybelse geskrifte te doen met die persepsies en interpretasies van premoderne mense" (Du Toit 2000:147). Op grond hiervan argumenteer hy dan dat die vertelling oor Jesus se maagdelike geboorte (of liewer maagdelike verwekking) verstaan moet word teen die agtergrond van dáárdie mense se leef- en kenniswêreld. Volgens hom hoef Christene wat in die postmoderne tydvak leef, nie die maagdelike geboorte as feit te aanvaar nie. "Dit maak nie regtig saak nie. Jesus se verlossingswerk berus nie op die maagdelike geboorte nie, maar op sy kruisdood en opstanding" (Du Toit 2000:148). My reaksie tydens die lees van hierdie stelling was: Maar die kerk het nog altyd die maagdelike geboorte met die leer van die erfsonde in verband gebring. Sonder die maagdelike geboorte, sou Jesus deel gehad het aan die erfsonde en kon Hy nie 'n volkome verlosser gewees het nie (vgl die Heidelbergse Kategismus, Sondag 14, vraag en antwoord 35). Na my mening hou Du Toit se stelling dat die maagdelike geboorte nie belangrik is nie, nie steek nie. Dis 'n wesenlike onderdeel van die meesterverhaal van die Christendom.

Met hierdie kritiese opmerkings wil ek allermins te kenne gee dat Ben du Toit se boek geen waarde het nie. Die waarde daarvan is geleë in die feit dat dit erns maak met ons wetenskaplike kennis en ons leefwêreld. Dwarsdeur die boek beklemtoon hy dat die Bybelse geskrifte uit premoderne tye kom en dus die stempel dra van dáárdie mense se kennis- en

9 Vergelyk die artikels en briefwisselings in Die Kerkbode van 16 Maart, 18 Mei, 1 Junie, 15 Junie en 20 Julie 2001. 
leefwêreld. Dis 'n belangrike stelling wat 'n groter rol in ons lees en verstaan nie net van die Bybelboeke nie, maar ook van die ekumeniese belydenisse en die gereformeerde belydenisskrifte behoort te speel.

\section{INTERMEZZO 2: DIE BOETMAN-DEBAT}

Meimaand 2000 en die titel "Boetman is die bliksem in" sal vir ewig in my geheue ingeprent bly. Dis die maand waarin Chris Louw (uitvoerende regisseur van die aktualiteitsprogramme Monitor en Spektrum op radio) 'n ope brief (Louw 2000) aan Willem de Klerk geskryf het na aanleiding van sy boek Afrikaners: Kroes, kras, kordaat (2000) ${ }^{10}$. 'n Verkorte weergawe daarvan is op Vrydag 5 Mei in die oggendblad Beeld gepubliseer en dit het tot 'n ongekende reaksie gelei. Dit was asof 'n damwal gebreek het. Verskeie briefskrywers het Chris Louw bedank vir die ontboeseming en sy moed om die ouer geslag wat apartheid as politieke beleid help vestig en hulle seuns aan 'n sinnelose Grensoorlog laat deelneem het, aan te vat. Chris Louw het sy ope brief, 'n handvol van die koerantbriewe, verdere vertellings oor sy belewenis van die apartheidsjare, en die geskiedenis van die onderhandelings wat tot die bewindsverandering in 1994 gelei het, later in boekvorm gepubliseer. Hierdie boek met die titel Boetman en die swanesang van die verligtes (Louw 2001) het my herinner aan die boek van Tienie Swanepoel (1997). Beide skrywers is seuns van oud-sendelinge in die gereformeerde tradisie ${ }^{11}$ en dwarsdeur hulle boeke speel die Christelike godsdiens ' $n$ rol. Die vraag hoe dit gekom het dat die Christelike godsdiens in sy gereformeerde baadjie help vorm gee het aan die apartheidsbeleid spook by biede skrywers. So ook die kwessie dat godsdiens gebruik is om aan die Grensoorlog legitimiteit te verleen. Hier was 'n jonger geslag aan die woord wat besluit het om uit te breek sodat hulle nuut kon dink. Hierdie boeke het heelwat Afrikaanssprekende Christene aan die dink en aan die praat gesit oor die geloof waarmee hulle opgevoed is.

10 'n Brief van 'n persoon wat homself net as "Psigiater" geïdentifiseer het, het aan Chris Louw die impulse voorsien vir die skryf van die ope brief. Hierdie brief (Beeld 27 April 2000) was self 'n skerpsinnige reaksie op Willem de Klerk se boek Afrikaners: Kroes, kras, kordaat (2000).

11 Tienie Swanepoel se pa was predikant in die Ned Geref Kerk en later sendeling in Venda. Chris Louw se pa was 'n Gereformeerde predikant en later sendeling in Mamelodi (Tshwane). 


\section{TEOLOGIE NA APARTHEID}

Die bewindsverandering in Suid-Afrika en die eeu- en millenniumwending het 'n vrugbare teelaarde geskep vir indringende gesprekke oor die Christelike godsdiens. Die gesprek wat in 1998 begin het, het mettergaan momentum gekry en kort voor lank het mense oor byna elke aspek van die Christelike godsdiens gesprekke gevoer. 'n Jonger geslag was bereid om die tradisionele dogmas en geloofsoortuigings aan indringende ondersoek te onderwerp.

In die gesprekke wat op Ben du Toit se boek gevolg het, het die dreigement van leertug telkens na vore gekom, maar dit het die "ondervraers"12 nie weerhou om die gesprekke voort te sit en om nuwe temas aan te roer nie. Die volgende temas het naas die gesprek oor die oerknalteorie en die evolusieleer opgeduik: (1) die gesag en verstaan van die Bybel; (2) die Christelike geloof en ander godsdienste (3) die historiese Jesusvraagstuk en 'n moontlike nuwe hervorming binne die Christendom.

\subsection{Die gesag en verstaan van die Bybel}

In dieselfde jaar as dié een waarin Willem de Klerk se boek Die vreemde God en sy mense verskyn het, is die boek Perspektiewe op die Bybel gepubliseer (Spangenberg 1998). Hierdie boek wou lesers inlig oor paradigmaverskuiwings op die terrein van die studie van die Bybel. Die boek het nie in daardie jaar mense se aandag getrek nie, maar die kwessie van die gesag en die verstaan van die Bybel het al hoe dringender geword — veral na die bewindsoorname in 1994. Reeds die vorige jaar het 'n groep Stellenbossers die boek Die Bybel in fokus: Leesgids vir 'n nuwe tyd (Jonker, Botha \& Conradie 1997) gepubliseer. Dit was ook 'n poging om lidmate op die grondvlak van die kerk in te lig oor nuwere teorieë van verstaan en nuwere inligting rondom die literatuursoorte in die Bybel. Ook daardie boek het nie onmiddellik aandag getrek nie.

Die debat oor die gesag en verstaan van die Bybel het eers gedurende 2001 werklik op dreef gekom toe drie teoloë uitgenooi is om deel te neem aan Die Burger se lesingsreeks tydens die Klein Karoo Nasionale

12 Willem de Klerk het hierdie benaming gemunt vir gelowiges wat indringende vrae stel en na antwoorde soek. Volgens hom het die tyd aangebreek "... vir die nuwe groot weeg, sodat die Christendom bevry kan word van opvattings wat al hoe meer deur 'n al groter getal teoloë bevraagteken word"' (De Klerk 1998:24). 
Kunstefees op Oudsthoorn ${ }^{13}$. Willem Jordaan (2001) het hieroor verslag gelewer in die rubriek "Forum" in Die Burger en Frits Gaum (2001) in die rubriek "Vuurhoutjie" in die Algemene Kerkbode. Adrio König (2001a) het kort hierna tot die debat toegetree in die rubriek "Vuurhoutjie" in Die Kerkbode. Ook Gereformeerdes het aan die debat begin deelneem, maar weens ander kwessies binne die Gereformeerde Kerke. Gerrie Snyman het tydens 'n werksessie oor "Vroue in die kerk en samelewing" op Potchefstroom gedurende 2001 die wyse waarop die Bybel misbruik word om vroue in die Gereformeerde kerke uit kerklike ampte te weer, onder die vergrootglas geplaas (Snyman 2002:1-26) ${ }^{14}$. In die Ned Geref Kerk het die vraagstuk oor homoseksuele lidmate gedurende 2002 en 2003 die gesprek oor die gesag en verstaan van die Bybel vir die soveelste keer na vore gedwing en die gesprek daaroor is nog nie afgehandel nie.

\subsection{Die Christelike geloof en ander godsdienste}

Gedurende Desember 1999 het die Parlement van die Wêreld se Godsdienste in Kaapstad vergader en dit het heelwat Christene oor die uniekheid van die Christelike godsdiens laat nadink. Sakkie Spangenberg het twee artikels vroeg in Januarie 2000 oor dié onderwerp in koerante gepubliseer (2000a, 2000b). Daar was enkele reaksies daarop, maar die gesprek oor die Christelike godsdiens se verhouding tot ander godsdienste het eers werklik vlam gevat toe Francois Wessels 'n artikel daaroor in Die Kerkbode se rubriek "Forum" gepubliseer het (2000). In dié betrokke artikel het hy na Spangenberg se standpunte verwys. Hierdie artikel het heelwat mense na hulle penne laat gryp en standpunte vir en teen 'n Christendom sonder absoluutheidsaansprake ${ }^{15}$ is geformuleer. Die debat is selfs in die Engelstalige dagblad The Star en in die Sondagkoerant Rapport gerapporteer. Max du Preez (2000) het in die rubriek "Opinion" in The Star gevra of dit nie die soort weg is wat Christene in hierdie land moet bewandel nie, en Mariechen Waldner van Rapport was van mening dat die dae van ketterjag verby is. Volgens haar oordeel is Christene in die

13 Die drie teoloë was Frits Gaum (redakteur van Die Kerkbode) Christina Landman en Sakkie Spangenberg (beide van Unisa).

14 Dit was nie die eerste keer dat Gerrie Snyman oor die gesag en verstaan van die Bybel gepraat het nie. Sy eerste bydrae tot hierdie debat het reeds in die vroeë negentigs verskyn (vgl Snyman 1992).

15 Reinhold Bernhardt (1994) het hieroor 'n lesenswaardige boek geskryf. 
gereformeerde tradisie gereed vir 'n oopgesprek oor die Christelike godsdiens se verhouding tot ander godsdienste (Waldner 2000)

Die gebeure op 11 September 2001 toe twee vliegtuie in die torings van die Wêreldhandelsentrum in New York vasgevlieg het, het die gevaar wat fundamentalisme en godsdiensfanatisme vir die wêreld inhou, onderstreep. Net soos die Tweede Wêreldoorlog (1939-1945) teoloë se denke gedurende die twintigste eeu ingrypend beïnvloed het, so gaan hierdie gebeure 'n onuitwisbare stempel afgedruk op teoloë se denke in die een-en-twintigste eeu. Hans Küng (1993) se waarskuwing dat ons nie kan hoop om vrede op aarde te bereik as godsdiensleiers nie met mekaar gesprek voer nie, het skielik geblyk nie 'n leë waarskuwing te wees nie. Sommige mense se godsdienstige oortuigings kan vir ander mense onheil en die dood inhou. Dit sien ons nie net in die VSA, Israel en Irak nie, maar in verskeie ander lande. Miskien kan die nuwe beleid oor godsdiens op skool in ons land bydra tot 'n beter verstaan van mekaar en tot groter respek vir ander mense en hulle oortuigings. Die wêreld vra na leiers met 'n ruim perspektief en 'n ruim hart en verstand. Sonder sulke leiers is ons gedoem tot ondergang.

\subsection{Die historiese Jesus-navorsing en 'n nuwe hervorming}

Die historiese Jesus-navorsing was 'n onderwerp waarmee slegs enkele Suid-Afrikaanse Nuwe-Testamentici hulle oor die afgelope aantal jare besig gehou het. Teologiese en Bybelkundestudente het wel daarvan te hore gekom, maar gewone kerklidmate het geen benul gehad van dié soort ondersoek nie. Hierdie situasie het skielik verander toe Neels Jackson 'n onderhoud met Andries van Aarde oor sy boek Fatherless in Galilee: Jesus as child of God gedurende Oktober 2000 gepubliseer het (Jackson 2000a). Volgens Van Aarde sit daar meer in die vertellings dat Jesus sonder ' $n$ vader gebore is. As 'n mens hierdie inligting teen die agtergrond van die destydse wêreld lees, is dit verstaanbaar waarom Jesus hom met die randfigure van dáárdie samelewing geassosieer het en aan hulle verkondig het dat God hulle Vader is ${ }^{16}$.

16 Van Aarde (2001b:99) som die inhoud van sy boek soos volg op: "My boek handel oor die historiese Jesus wat 'n leegheid as gevolg van sy vaderloosheid gevul het met sy vertroue in God as 'n inklusiewe vaderfiguur. Onder die geloofsbelydenisse van die vroegste volgeling van Jesus vind ons die verwoording van hulle ervaring van geloof in Jesus as Seun van God. Hierdie ervaring kan ook 
Neels Jackson het die artikel opgevolg met 'n tweede artikel met die titel "Die groot soektog na die ware Jesus" (Jackson 2000b). Verskeie briefskrywers het op hierdie en ander artikels gereageer (Beeld 19 Oktober; 20 Oktober), terwyl 'n aantal teoloë ook aan die debat deelgeneem het (Craffert 2000; König 2000; Van Wyk 2000). Teoloë van die Gereformeerde Kerke het self op 31 Oktober 'n verklaring uitgereik wat met die debatte verband hou (Beeld 31 Oktober 2000).

Die debat oor die gevolge van hierdie soort navorsing het vroeg in 2002 ongekende momentum beleef toe Piet Muller (2002a) 'n artikel in Beeld gepubliseer het. Hy het as toekomskundige daarop gewys dat 'n nuwe hervorming binne die Christendom op hande is. Murray Janson (2002) het Muller aangevat en hom daarvan beskuldig dat hy met Christus gebreek het. 'n Lewendige debat het hierop gevolg waaraan verskeie briefskrywers (Beeld 25 Maart, 26 Maart, 27 Maart, 3 April 2002) en artikelskrywers (Jackson 2002; König 2002a; Spangenberg 2002a, 2002b, 2002c; Van Niekerk 2002) deelgeneem het. Selfs die redakteur van Die Kerkbode het in 'n hoofartikel gereageer op die stelling dat 'n nuwe hervorming voor die deur staan (15 Februarie 2002).

Die besoek van Dominic Crossan (een van die lede van die JesusSeminaar) gedurende April 2002 aan Suid-Afrika het verdere momentum aan die debat verleen. Na sy besoek het 'n handvol akademici by Unisa vergader en besluit dat die tyd ryp is om mense oor die navorsing rondom die historiese Jesus in te lig. Die Nuwe Hervorming-gespreksforum het so tot stand gekom. Van die aanvanklike groep het slegs vyf met die idee deurgedruk $^{17}$. Inligtingsessies is in Johannesburg, Bloemfontein en Newcastle gehou, 'n boek met die titel Die Nuwe Hervorming (Muller $2002 b$ ) is gepubliseer en ' $n$ webbladsy (www.nuwe-hervorming.org.za) is in die lewe geroep.

'n Interessante feit rondom die idee van 'n nuwe hervorming is dat biskop John AT Robinson reeds in 1965 'n boek met die titel The New Reformation? gepubliseer het. Hierin het hy onomwonde gestel dat 'n nuwe hervorming binne die Christendom voor die deur staan. In die boek maak hy onder andere die volgende insiggewende stelling: "Terwyl die

vir die baie vaderlose kinders en enkellopende, 'patriarglose' vroue die herstel van kwaliteitslewe meebring".

17 Die vyf was P J J (Pieter) Botha, P F (Pieter) Craffert, P (Piet) Muller, I J J (Sakkie) Spangenberg en J P H (Hansie) Wolmarans. 
Protestantse Hervorming gefokus het op die vraag 'Waar vind ek 'n genadige God?', gaan die nuwe hervorming fokus op die vraag 'Waar vind ek 'n genadige medemens?"' (Robinson 1965:33).

Ook Willem de Klerk het in sy boek Die vreemde God en sy mense oor die moontlikheid van 'n nuwe hervorming bespiegel. Hy het dit só verwoord: (De Klerk 1998:23):

"Eintlik wag hulle [die ondervraers] op 'n nuwe hervorming wat krities kyk na die kerk se dogmatiek oor: die Bybel se gesag en status en hoe gelowiges die Bybel moet benader; die formuleringe van die belydenisskrifte wat op baie punte weer getoets moet word, want dit was mensewerk van die jaar toet; sentrale leerstukke soos die uitverkiesingsleer, die leer oor die erfsonde, God se voorsienigheid en wêreldbestuur, die Drie-eenheid van God".

Die moontlikheid dat ' $n$ nuwe hervorming hom binne die Westerse Christendom kan voltrek, word na my mening al hoe waarskynliker. Daar bestaan reeds groepe in die VSA, Engeland en Nederland wat elkeen op hulle eie manier uitdrukking gee aan 'n nuwe verwoording en belewing van die Christelike geloof en prominente teoloë skryf oor die saak (vgl Wiersinga 1992, Cupitt 2001; Spong 2002).

\subsection{Walgooi teen die nuwere idees}

'n Aantal Afrikaanssprekende teoloë het onder leiding van Piet Meiring in 2001 'n boek gepubliseer waarin hulle probeer het om die "ou sekerhede" van die Christelike geloof en die "kernwaarhede van die evangelie" weer "blink te poets" (Meiring 2001:10). Die boek, met die titel So glo ons, dra die karakter van 'n moderne katkisasieboek. Byna elke onderafdeling van die meesterverhaal van die Christendom word onder die loep geneem van die sonde (Joubert, S 2001), deur die verlossing (Cillers 2001) tot by die wederkoms (Janse van Rensburg 2001). Belangrike sake soos die historiese Jesus (Du Rand 2001) en die Bybel as God se Woord (Van Zyl 2001) word ook aangeroer. Al het van die skrywers met nuwere verwoordings na vore gekom, het hulle deur die bank so getrou as moontlik probeer bly aan die meesterverhaal van die Christendom.

In die volgende jaar (2002) het dieselfde uitgewery wat die vorige boek gepubliseer het ook 'n boek oor die lees en verstaan van die Bybel die lig laat sien. Dit dra die titel Hoe lees ons die Bybel? Vier skrywers uit die geledere van die groep wat So glo ons (Meiring 2001) geskryf het, het 
deelgeneem aan die skryf van hierdie een. Hulle is Jan van der Watt, Stephan Joubert, Jan du Rand en Piet Naudé. Ook hierdie boek is bedoel om 'n middeweg tussen die tradisionele gereformeerde sienings van die Bybel en die moderne Bybelwetenskap aan te dui, en om te hou by die meesterverhaal van die Christendom. God word hierin nog beskou as die primêre skrywer van die Bybel (vgl Van der Watt 2002:53-54) ${ }^{18}$, en die verhale in die Bybel word gelyk gestel aan die meesterverhaal van die Christendom (vgl Joubert, S 2002:101-110; Du Rand 2002:189-191). Die vervangingsleer (die siening dat die Christelike godsdiens Judaïsme vervang het) speel ook hierin 'n beduidende rol $^{19}$. Vergelyk die volgende stelling van Stephan Joubert (2002:102):

"Maar met die koms van Jesus, as die absolute hoogtepunt van God se verlossingshandeling, het hierdie Ou-Testamentiese rituele (die besnydenis en die pasga) oorbodig geraak. Dit is vervang met die doop en die nagmaal. [...] Die skaduwee van die kruis het immers op hierdie twee rituele geval en hulle vervang met die doop en die nagmaal".

Ten spyte van hulle pogings om die Christelike geloof eietyds te formuleer en om met die nuwere Bybelkennis te werk, ontkom die skrywers nie aan die suigkrag van 'n histories-letterlike interpretasie van die Bybelverhale nie. So word die verhaal van Adam en Eva (Joubert, S 2002:105), die vloed- en die intogverhaal (Naudé 2002:195) die verhaal van die skeur van die tempelvoorhangsel (Joubert, S 2002:105) en nog ander Bybelverhale histories-letterlike gelees. Na my mening is dit omdat die meesterverhaal (die oorkoepelende verlossingsverhaal) die bril is aan die hand waarvan die skrywers die Bybel lees. Daardie verhaal vereis dat Adam en Eva werklike mense moet wees en dat daar eendag 'n werklike wederkoms gaan wees ${ }^{20}$.

18 Die siening dat God die primêre outeur van die Bybel en dat die menslike skrywers slegs sekondêre skrywers is, is ' $n$ gewilde siening binne die Ned Geref Kerk. Hierdie beskouing kan teruggevoer word na die Protestantse Ortodoksie (vgl Spangenberg 2002d).

19 Die vervangingsleer ("suppersessionist theology") is nog springlewendig binne die Ned Geref Kerk, daarom onderhou dit 'n sendingaksie bekend as "Sending onder die Jode".

20 Die volgende stelling van Günther Weber (1998:32): "The interpretation in the Bible, that God has chosen the people Israel, made a covenant with it, so that it 
In 2001 en 2002 het Adrio König (afgetrede sistematiese teoloog aan Unisa) ook vanuit ' $n$ behoudende hoek oor Jesus en die Bybel geskryf ${ }^{21}$. In sy boek oor Jesus speel die vervangingsleer 'n groot rol (vgl König 2001b:16, 30) en gebruik hy die ou uitgediende benamings soos "laatJoodse apokaliptiek", "laat-Joodse literatuur" en "laat-Joodse opvattings" steeds (König 2001b:26, 68, 92, 121, 184). Cees den Heyer (2001:124) se opmerking "Het woord Spätjudentum is uit de wetenschappelijke literatuur verdwenen en vervangen door die historisch correcte term Frühjudentum" wys dat König nie kennis geneem het van die verskuiwings op die terrein van die Bybelwetenskappe nie. Dit geld ook van sy boek oor die Bybel. Alhoewel die boek heelwat goeie inligting bied, is dit duidelik dat hy vanuit 'n behoudende standpunt skryf en dat sy sienings deur die meesterverhaal van die Christendom gedra word. Daarom sê hy dikwels dat ons sekere sake in "heilshistoriese lig" moet lees en verstaan (König 2002b:190) en dat ons "die groot lyne in die Bybel" in ag moet neem (König 2002b:218). Hierdie "heilshistoriese lig" en "groot lyne" is niks anders as die lyne van die meesterverhaal nie. Die Bybel word dus steeds met die "bril" van die meesterverhaal gelees.

Die Stellenbosche dogmatikus, Dirkie Smit, het in hierdie tydperk 'n trilogie gepubliseer wat niks anders is as 'n uitleg van die Bybel aan die hand van die geloofsbelydenis van Nicea (2001a, 2001b, 2003). Eksegese in die tradisie van die historiese kritiek is dit allermins.

\section{SLOT: VIER RIGTINGS}

Oor hoe Afrikaanssprekende Christene van die gereformeerde tradisie vandag oor God praat, het daar die afgelope vyf jaar vier duidelike rigtings uitgekristaliseer. Ons kan dit soos volg weergee: (1) die meesterverhaal staan bo verdenking en moet met ywer verdedig word; (2) die

becomes great and strong in a land 'flowing with milk and honey', is a timeconditioned interpretation of Israel's history from the perspective of its own interest", sou dalk nog vir Ben du Toit aanvaarbaar wees, maar nie vir hierdie vier skrywers nie.

21 In Augustus 2001 het Adrio König saam met Jan du Rand, Stephan Joubert en Jan van der Watt 'n artikel in Die Kerkbode geskryf waarin hulle Ben du Toit se sienings heftig gekritiseer het. Die slotparagraaf van die artikel weerspieël die hoek waaruit hulle skryf: "Ter opsomming vind ons dit moeilik om Du Toit te plaas. Ons meen hy skipper rond tussen modernisme en postmodernisme, en hou uiteindelik min van die evangelie oor, té min om dit nog die moeite werd te maak" (Du Rand et al 2001:10). 
meesterverhaal maak op bepaalde punte nie meer sin nie en moet met die nuwere wetenskaplike kennis geharmonieer word; (3) die meesterverhaal maak glad nie meer vir mense sin nie en kan nie met die nuwere wetenskaplike kennis geharmonieer word nie - 'n alternatiewe tradisie is die enigste uitweg uit hierdie doodloopstraat; (4) neem afskeid van die Christelike tradisie en verken 'n ander godsdienstige tradisie ${ }^{22}$.

Vir die eerste keer in dekades word daar onder Afrikaanssprekendes weer goeie teologiese gesprekke gevoer en is ons teologie nie meer uit die oudedoos en parogiaal nie. Sommige kerklidmate is ietwat onthuts oor wat hulle hoor en lees, maar daar is ook 'n beduidende aantal wat volwasse, wydbelese en goed toegerus is om saam te kan gesels. Na my mening sal daar nog vele gesprekke en debatte in die toekoms gevoer word. Of 'n nuwe hervorming wel eendag sal realiseer, sal net die toekoms ons leer.

\section{Literatuurverwysings}

Alberts, L 1996. Geloof versus wetenskap: Perspektiewe op die versoenbaarheid van die Bybel en die bevindings van die natuurwetenskap. Vereeniging: CUM.

Barton, J 1988. People of the Book? The authority of the Bible in Christianity. London: SPCK.

Beeld 27 April 2000. Briewe, 10.

Beeld 5 Mei 2000. Boetman is die bliksem in, 13.

Beeld 19 Oktober 2000. Briewe, 10.

Beeld 20 Oktober 2000. Briewe, 10.

Beeld 31 Oktober 2000. Teoloë gee op Hervormingsdag perspektief op Skrif, 7.

Beeld 25 Maart 2002, Briewe, 10.

Beeld 26 Maart 2002, Briewe, 10.

Beeld 27 Maart 2002, Briewe, 8.

Beeld 3 April 2002, Briewe, 8.

Bernhardt, R 1994. Christianity without absolutes. London: SCM.

Cilliers, J 2001. Hoe word 'n mens gered? In Meiring 2001, 185-198.

22 Daar is nog nie 'n beduidende aantal Afrikaanssprekendes wat hierdie rigting inslaan nie, maar Kobus Krüger en Johann Roussouw is voorbeelde van hierdie tendens. Hulle vind aanklank by Boeddhisme (vgl Krüger 2003:3-4; Van der Merwe \& Rautenbach 2003). 
Craffert, P F 2000. 'Kyk na historiese Jesus uit die perspektief van kultuur', Beeld 27 Oktober, $\mathrm{p} 23$.

Cupitt, D 2001. Reforming Christianity. Santa Rosa: Polebridge.

De Klerk, W J 1998. Die vreemde God en sy mense. Kaapstad: Human \& Rousseau.

-, 2000. Afrikaners: Kores, kras, kordaat. Kaapstad: Human \& Rousseau.

Den Heyer, C J 2001. Ruim geloven: Een theologisch zelfportret. Zoetermeer: Meinema.

Du Preez, M 2000. Judge less, love more is way to go. The Star 24 August 2000, 9.

Durand, J 2002. Hoe my gedagtewêreld verander het: Van ewige waarhede tot gekontekstualiseerde metafore. NGTT 43, 64-70.

Du Rand, J A, Joubert, S, König, A, Van der Watt, J 2001. Té min bly oor. Die Kerkbode 17 Augustus 2001, 10.

Du Rand, J A 2001. Wat weet ons van Jesus van Nasaret? In Meiring 2001, 43-55.

-, 2002. Dagsê, Vriend Tydgees. In Van der Watt, Joubert, Du Rand, \& Naudé, 2002, 141-191.

Du Toit, B J 2000. God? Geloof in 'n postmoderne tyd. Bloemfontein: CLF.

Eloff, J N 1968. Die dilemma van die moderne Christenbioloog: Intreerede gelewer op 6 Mei 1975. Bloemfontein: Universiteit van die Oranje-Vrystaat.

Ferreira, A 1996. Die dag toe ons God gevang het: 'n Persoonlike soeke na sin. Kaapstad: Queillerie.

Gaum, F 2001. Die Bybel vandag! Algemene Kerkbode 12 April, 4.

Henry, A (ed) 1987. Biblia Pauperum: A facsimile and edition. New York: Cornell University Press.

Jackson, N 2000a. Bybelverhale van vaderlose Jesus 'nie letterlik waar.' Beeld 6 Oktober 2000, 9.

-, 2000b. Die groot soektog na die ware Jesus. Beeld 13 Oktober 2000, 9.

-, 2002. Op soek na Jesus in 'n boeke-woud. Beeld 22 Maart 2002, 11.

Janse van Rensburg, F 2001. Waar gaan alles eindig? In Meiring 2002, 280-300.

Janson, M 2002. Muller het met Christus gebreek: Jesus-seminaar se hervorming is wég van Hom af. Beeld 13 Februarie 2002, 14.

Jonker, L C, Botha, J, Conradie, E 1997. Die Bybel in fokus: Leesgids vir 'n nuwe tyd. Kaapstad: LuxVerbi.

Jordaan, W 2001. Hoe lees mense die Bybel vandag? Burger 12 April, 5.

Joubert, G 1997. Die groot gedagte: Abstrakte weefsel van die kosmos. Kaapstad: Tafelberg. 
Joubert, S 2001. Sonde, die stryd teen stukkende verhoudings. In Meiring 2001, 216228.

-, 2002. Dagsê, Meneer Bybel. In Van der Watt, Joubert, Du Rand, \& Naudé, 81140.

Kalsbeek, L 1968. Schepping en wording. Baarn: Bosch \& Keuning.

Kerkbode 16 Maart 2001. Standpunte, 12.

Kerkbode 18 Mei 2001. Briewe, 10-11.

Kerkbode 1 Junie 2001. Briewe, 10.

Kerkbode 15 Junie 2001. Briewe, 10-11.

Kerkbode 20 Julie 2001. Briewe, 12-13.

Kerkbode 15 Februarie 2002. 'n Ou vervorming, 6.

König, A 2000. Lyne, tradisie loop deur Bybel wat gesag vir Christene het. Beeld 27 Oktober, 23.

-, 2001a. 'Die Bybel sê ...'? Nee, die Bybel sê niks. Die Kerkbode 4 Mei 2001, 5.

-, 2001b. Die helfte is my nooit oor Jesus vertel nie: 'n Kyk op die Een wat jou lewe verander. Wellington: LuxVerbi.

-, 2002a. "Kruisdood is vir húlle afskuwelik": Nuwe Hervorming ry maar op ou donkies. Beeld 28 Maart 2002, 14.

-, 2002b. Ek glo die Bybel - ondanks al die vrae: Vaste bankens vir 'n tyd waarin die Bybel in die gedrang is. Wellington: LuxVerbi.

Krüger, J S 2003. Spoor: Religieus-akademiese staptog deur 'n kwarteeu. Pretoria: Aurora.

Küng, H, Van Ess, J, Von Stietencron, H, Bechert, H 1993. Christianity and the World Religions: Paths of dialogue with Islam, Hinduism, and Buddhism. London: SCM.

Kuhn, T S 1970. The structure of scientific revolutions. 2nd ed. Chicago: University of Chicago Press. (International Encyclopedia of Unified Science).

Louw, C 2000. Ope brief aan Willem de Klerk. Dainfern: Praag.

-, 2001. Boetman en die swanesang van die verligtes. Kaapstad: Human \& Rousseau.

Meiring, P J (red) 2001. So glo ons: Gelowige nagedink oor God, die Bybel en ons leefwêreld. Vereeniging: CUM.

Muller, P 2002a. 'Nuwe Hervorming' met nuwe vrae. Beeld 25 Januarie 2002, 7.

-, (red) 2002b. Die Nuwe Hervorming. Pretoria: Protea Boekhuis.

Naudé, P 2002. Dagsê, Kollega Kerkleer. In Van der Watt, Joubert, Du Rand, \& Naudé, 193-212. 
Nel, A 2003. Op soek na God ... buite die kerk? Wellington: LuxVerbi.

Ord, D R \& Coote, R B 1994. Is the Bible true? Understanding the Bible today. New York: Orbis.

Robinson, J A T 1965. The New Reformation? London: SCM.

Smit D J 2001a. Lig uit Lig: Wat Christene bely oor Jesus Christus. Wellington: LuxVerbi.

-, 2001b. Wat Here is en lewend maak: Wat Christene bely oor die Heilige Gees. Wellington: LuxVerbi.

-, J 2003. Vernuwe! — na die beeld van ons Skepper: Wat Christene bely oor God die Skepper. Wellington: LuxVerbi.

Snyman, G F 1992. Binnegevegte in die GKSA: Verskuiwing van 'plausibility structures'? In die Skriflig 26, 351-367.

-, 2002. Telling women to be like men: Some theoretical aspects regarding the interpretation of the Bible on gender issues. Koers 67, 1-26.

Spangenberg, I J J 1998. Perspektiewe op die Bybel. Pretoria: J L van Schaik.

-, 2000a. Groot debat vir Christene het maar pas begin. Rapport 2 Januarie 2000, 11.

-, 2000b. Godsdiens-kreatief: Dié met ander geloof is medemens. Beeld 10 Januarie 2000,8 .

-, 2002a. Kerk kan nie bekostig om lidmate in duister te hou oor Bybel. Beeld 1Maart 2002, 7.

-, 2002b. Die godsdiensdebat: Te maklik word mense tot ketter gemaak. Rapport 3 Maart 2002, 15.

-, J 2002c. Nuwe hervorming is aan 't versnel: Herformuleer geloof in die lig van nuwe kennis. Beeld 20 Mei 2002, 8.

-, 2002d. Hoe dink vandag se mense oor die Bybel? Verbum et Ecclesia 23(1), 183195.

Spong, J S 2002. A new Christianity for a new world: Why traditional faith is dying and how a new faith is being born. New York: HarperCollins.

Swanepoel, T 1997. My hart wil Afrika. Kaapstad: Queillerie.

Van Aarde, A 2001a. Fatherless in Galilee: Jesus as child of God. Harrisburg: Trinity Press International.

-, 2001b. Die vaderlose Jesus. Fragmente 7, 91-100.

Van der Merwe, K \& Rautenbach, E 2003. Zen-vrede. Insig Desember 2003, p 47-49.

Van der Watt, J 2002. Verstaan jy wat jy lees? In Van der Watt, Joubert, Du Rand, \& Naudé, $11-80$. 
Van der Watt, J, Joubert, S, Du Rand, J \& Naudé, P 2002. Hoe lees ons die Bybel: 'n Soeklig op die rol van die Woord en hoe om dit te vertolk in hedendaagse tye. Vereeniging: CUM.

Van Niekerk, A 2002. 'n Woord onderweg: Nadenke oor Jesus. Beeld 16 Februarie 2002,8 .

Van Rensburg, F J 2001. Waar gaan dit alles eindig? In Meiring, 280-300.

Van Zyl, H 2001. Is die Bybel nog God se Woord? In Meiring, 72-87.

Vermes, G 1993. The religion of Jesus the Jew. Minneapolis: Fortress.

Waldner, M 2000. Die "brandstapel" is nat: Die gereformeerde kerke in SA is reg vir die oop gesprek. Rapport 27 Augustus 2000, 3.

Weber, G 1998. I believe, I doubt: Notes on Christian experience. London: SCM.

Wessels, F 2000. Verskillende godsdienste nie maar God se "veelkleurige genade"? Die Kerkbode 18 Augustus 2000, 9.

Wiersinga, H 1992. Geloven bij daglicht: Verlies en toekomst van een tradisie. Baarn: Ten Have.

Wiese, T 2003. Verlang jy nog na die kerk? Insig Desember 2003, 45.

Woord \& Daad 2002 (no 380), 11-15. 